\title{
Effect of gaseous anaesthesia on blood carbon dioxide measurements
}

\author{
R. R. OGILVIE AND G. F. A. HOWIE \\ From the Departments of Surgery and Radiology, University of St. Andrews, and \\ Royal Infirmary, Dundee
}

SYNOPSIS The present study of the effect of two common anaesthetic gases on blood acid-base parameters shows that the micro-Astrup measurement of carbon dioxide tension is not invalidate $\dot{\phi}_{0}$ by the presence of nitrous oxide. This result was anticipated from the theoretical aspect of this technique. The mean error involved in estimating plasma carbon dioxide content in the presence o nitrous oxide using the volumetric Van Slyke apparatus without absorption of carbon dioxide by sodium hydroxide can be of the order of $25 \%$. No such effect was measurable in estimating carbon dioxide contents in the presence of halothane.

The degree of respiratory alkalosis during anaesthesia reported in earlier papers (Walker Morgan, Breckenridge, Watt, Ogilvie, and Douglas, 1963; Morgan, Ogilvie, and Walker, 1963 was greater than had been originally appreciated.

A 'false' increase in carbon dioxide content will also falsely increase buffer base or 'base excess'

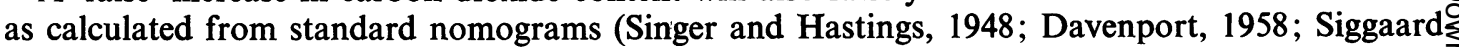
Andersen, 1963).

The measurement of blood acid-base parameters is becoming increasingly useful clinically, but in patients exposed to open-heart surgery certain routine methods may lead to considerable errors at the times when the patient is receiving a volatile anaesthetic. If the carbon dioxide content of plasma is estimated in the volumetric Van Slyke apparatus, volatile anaesthetic gases will cause falsely high results if, as is usual in routine practice, specific absorption by sodium hydroxide is not employed. The key factors then derived from the blood $p \mathrm{H}$ and carbon dioxide content, viz., $\mathrm{pCO}_{2}$ and base excess (or buffer base), will necessarily be in error, causing possible false interpretations of respiratory and metabolic changes.

Such discrepancies were found on reviewing our earlier work (Walker et al., 1963; Morgan et al., 1963) and led to a systematic study of the degree of error involved.

METHODS

Acid-base parameters were derived by coincidental use of the volumetric Van Slyke (Peters and Van Slyke, 1932) and micro-Astrup (Siggaard-Andersen, Engel, Jørgensen,

Received for publication 25 November 1964 and Astrup, 1960) techniques on arterial blood from $2 \overrightarrow{E 5}$ patients undergoing routine bilateral femoral arterio $\vec{B}$ graphy for peripheral vascular disease. Equal numbers had nitrous oxide or halothane as the gaseous anaese thetic

Blood was withdrawn from the femoral artery into siliconed, heparinized syringe after non-gaseous anaes? thesia was induced with succinylcholine chloride (Sce line) and sodium thiopentone (Pentothal) or sodiur methohexatone (Brietal) and before the injection of the radio-opaque contrast medium (Hypaque $45 \%$ ). This sample was then divided into two main aliquots, one for plasma carbon dioxide content measured by the volto metric Van Slyke apparatus without the addition of sodium hydroxide, the other for $p \mathrm{H}$ measurements ben fore and after equilibration with gases of known $\mathrm{pCO}_{3}$ values in the Astrup apparatus. In the case of the Vact Slyke estimations, the $\mathrm{pCO}_{2}$ values were calculatefo (Milch, Bane, and Roberts, 1957) from the measured blood $p \mathrm{H}$ values and carbon dioxide contents. In the micro-Astrup technique, blood carbon dioxide contents and $\mathrm{pCO}_{2}$ values were calculated using the Siggaards Andersen (1962) curve nomogram (Cartesian nomogram).

Anaesthesia was maintained with nitrous oxide/oxyge in the normal proportion of $3: 1$ or halothane 1 to $1 \frac{1}{2} 8$ in oxygen, and after 15 to 30 minutes another arterias blood sample was taken and treated similarly. Two blood samples were thus obtained from each patient, one 
before and one during the period of gaseous anaesthesia. In 14 patients the carbon dioxide content was also measured with the Natelson microgasometer (which is a modified manometric Van Slyke technique with sodium hydroxide used as a carbon dioxide absorbent; Natelson and Menning, 1955; Holaday and Verosky, 1956; Natelson, 1961) and in two by the colorimetric procedure in the Technicon AutoAnalyzer, in which evolved carbon dioxide acts on buffered phenolphthalein (Skeggs, 1960).

\section{RESULTS}

Discrepancies observed between the $\mathrm{pCO}_{2}$, values obtained by the micro-Astrup carbon dioxide equilibration technique and those derived from the blood $p \mathrm{H}$ values and carbon dioxide contents estimated by the volumetric Van Slyke apparatus in three patients undergoing open-heart surgery are shown in Table I. Serious discrepancies only occurred when the patient was anaesthetized, the Astrup $\mathrm{pCO}_{2}$ values during this period being lower than the corresponding Van Slyke values, on average by $25 \%$. However, estimations carried out by the two methods during the post-operative period generally agreed within reasonable limits of experimental error (Fig. 1).

TABLE I

pCO. VALUES CALCULATED USING THE VOLUMETRIC VAN SLYKE AND MICRO-ASTRUP TECHNIQUES SIMULTANEOUSLY DURING AND AFTER ANAESTHESIA IN THREE PATIENTS UNDERGOING OPEN-HEART SURGERY

\begin{tabular}{|c|c|c|c|c|}
\hline \multirow[t]{2}{*}{ Case } & \multicolumn{2}{|c|}{$\begin{array}{l}\text { In Theatre and during } \\
\mathrm{N}_{2} \mathrm{O} \text { Anaesthesia }\end{array}$} & \multicolumn{2}{|c|}{$\begin{array}{l}\text { Post-Operative after } \\
\text { Anaesthesia }\end{array}$} \\
\hline & Van Slyke & Astrup & lan Slyke & Astrup \\
\hline \multirow[t]{3}{*}{ I.K. } & $30 \cdot 4$ & $22 \cdot 0$ & \multirow[t]{3}{*}{$46 \cdot 9$} & \multirow[t]{3}{*}{$47 \cdot 8$} \\
\hline & $39 \cdot 9$ & $31 \cdot 8$ & & \\
\hline & $67 \cdot 7$ & $54 \cdot 8$ & & \\
\hline \multirow[t]{2}{*}{ N.I. } & $37 \cdot 5$ & $24 \cdot 5$ & \multirow[t]{2}{*}{$43 \cdot 3$} & \multirow[t]{2}{*}{$46 \cdot 5$} \\
\hline & $50 \cdot 4$ & $38 \cdot 0$ & & \\
\hline I. Mc. & $48 \cdot 6$ & 350 & 52.0 & $53 \cdot 8$ \\
\hline Mean & $45 \cdot 8$ & $34 \cdot 5$ & $47 \cdot 4$ & $49 \cdot 4$ \\
\hline
\end{tabular}

In the patients undergoing routine bilateral femoral arteriography, the values derived for carbon dioxide tensions before nitrous oxide anaesthesia by either the Astrup method or the Van Slyke technique agree on average within $5^{\circ}$, (Tables II and III). However, the 'carbon dioxide contents' and consequently the derived $\mathrm{pCO}_{2}$ values of the blood samples removed during nitrous oxide anaesthesia were greatly different, the Astrup results being about $25^{\circ}$ olower (Fig. 2).

The relative accuracy of the two methods used was compared with two others in routine work, the Natelson microgasometer and the AutoAnalyzer colorimetric procedure (Table III). Under conditions

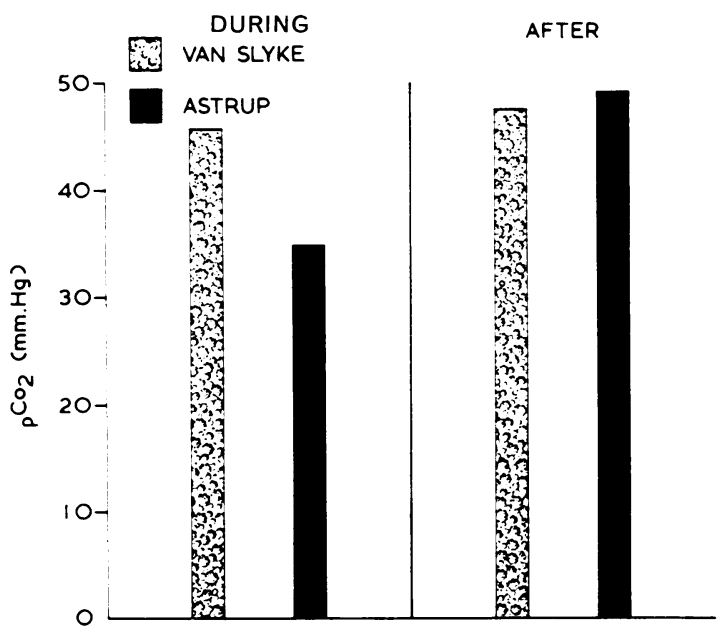

FIG. 1. Average $p C O_{2}$ values calculated using the volumetric Van Slyke and micro-Astrup techniques simultaneously during and after anciesthesia in three patients undergoing open-heart surgery. Good agreement in the results obtained by the two methods is seen after but not during anaesthesia.

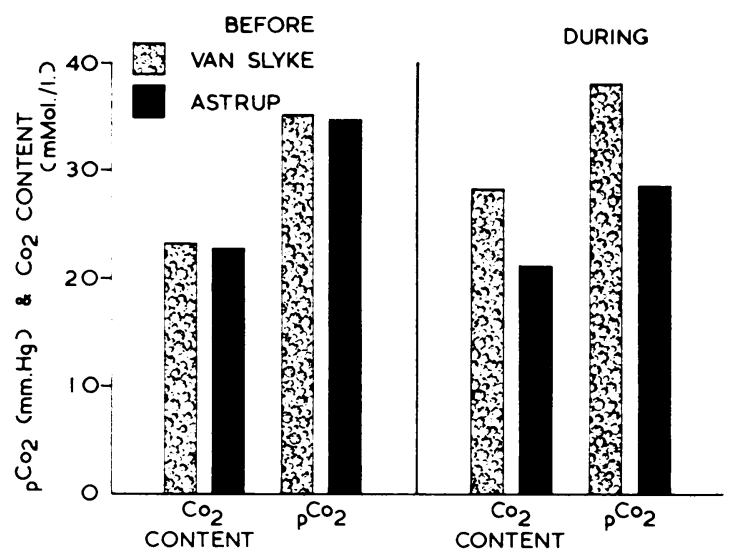

FIG. 2. Average carbon dioxide content and $p C O$, results measured or calculated simultaneously by the volumetric Van Slyke and micro-Astrup techniques before and during nitrous oxide anaesthesia in I) patients undergoing routine arteriography. Results from the two methods agree before anaesthesia but not during it.

of nitrous oxide anaesthesia the volumetric Van Slyke estimations were at variance with an error of about $25^{\circ}$.

When halothane was used as the gaseous anaesthetic there was no appreciable difference in the carbon dioxide content and the derived $\mathrm{pCO}_{2}$ using the Astrup, Van Slyke. and micro-Natelson techniques (Fig. 3). 
TABLE II

BLOOD CARBON DIOXIDE RESULTS MEASURED OR CALCULATED SIMULTANEOUSLY BY THE VOLUMETRIC VAN SLYKE AND MICRO-ASTRUP TECHNIQUES BEFORE AND DURING NITROUS OXIDE ANAESTHESIA IN 10 PATIENTS UNDERGOING ARTERIOGRAPHY

\begin{tabular}{|c|c|c|c|c|c|c|c|c|c|c|}
\hline \multirow{3}{*}{$\begin{array}{l}\text { Case } \\
\text { No. }\end{array}$} & \multicolumn{5}{|c|}{ Before $\mathrm{N}_{2} \mathrm{O}$ Anaesthesia } & \multicolumn{5}{|c|}{ During $\mathrm{N}_{2} \mathrm{O}$ Anaesthesia } \\
\hline & \multirow{2}{*}{$p \mathbf{H}$} & \multicolumn{2}{|c|}{$\mathrm{CO}_{2}$ Content (m.mol./1.) } & \multicolumn{2}{|c|}{$\mathrm{pCO}_{2}(\mathrm{~mm} . \mathrm{Hg})$} & \multirow{2}{*}{$p \mathrm{H}$} & \multicolumn{2}{|c|}{$\mathrm{CO}_{2}$ Content (m.mol./1.) } & \multicolumn{2}{|c|}{$\mathrm{pCO}_{2}(\mathrm{~mm} . \mathrm{Hg})$} \\
\hline & & Van Slyke & Astrup & Van Slyke & Astrup & & Van Slyke & Astrup & Van Slyke & Astrup \\
\hline 1 & $7 \cdot 459$ & $22 \cdot 2$ & $25 \cdot 8$ & $31 \cdot 0$ & 36.0 & $7 \cdot 443$ & 29.9 & $19 \cdot 7$ & $43 \cdot 2$ & $27 \cdot 4$ \\
\hline 2 & $7 \cdot 315$ & $26 \cdot 7$ & $26 \cdot 7$ & $51 \cdot 1$ & $51 \cdot 3$ & $7 \cdot 420$ & $29 \cdot 5$ & $24 \cdot 1$ & 44.9 & $36 \cdot 8$ \\
\hline 3 & $7 \cdot 487$ & $22 \cdot 2$ & $21 \cdot 9$ & $29 \cdot 1$ & $28 \cdot 7$ & $7 \cdot 494$ & $27 \cdot 1$ & $20 \cdot 5$ & 35.0 & $26 \cdot 5$ \\
\hline 4 & $7 \cdot 382$ & $22 \cdot 5$ & 20.6 & $37 \cdot 2$ & $34 \cdot 0$ & 7.618 & $26 \cdot 0$ & $12 \cdot 2$ & $25 \cdot 5$ & $12 \cdot 0$ \\
\hline 5 & $7 \cdot 410$ & $22 \cdot 2$ & $20 \cdot 3$ & $34 \cdot 6$ & $32 \cdot 3$ & $7 \cdot 360$ & $29 \cdot 8$ & $22 \cdot 3$ & $51 \cdot 7$ & $40 \cdot 5$ \\
\hline 6 & $7 \cdot 412$ & $23 \cdot 6$ & $23 \cdot 1$ & $36 \cdot 6$ & $35 \cdot 8$ & $7 \cdot 498$ & $27 \cdot 5$ & $22 \cdot 4$ & $35 \cdot 3$ & $29 \cdot 0$ \\
\hline 7 & $7 \cdot 412$ & $25 \cdot 4$ & $24 \cdot 6$ & $39 \cdot 3$ & $38 \cdot 3$ & $7 \cdot 412$ & $30 \cdot 7$ & $23 \cdot 2$ & $47 \cdot 6$ & $36 \cdot 0$ \\
\hline 8 & $7 \cdot 520$ & $20 \cdot 6$ & 20.5 & $25 \cdot 2$ & $25 \cdot 0$ & $7 \cdot 560$ & $27 \cdot 5$ & $20 \cdot 2$ & 30.8 & $22 \cdot 5$ \\
\hline 9 & $7 \cdot 475$ & $23 \cdot 0$ & $20 \cdot 8$ & 31.0 & $27 \cdot 7$ & $7 \cdot 605$ & $28 \cdot 2$ & $18 \cdot 5$ & $28 \cdot 4$ & $18 \cdot 5$ \\
\hline 10 & $7 \cdot 410$ & $24 \cdot 7$ & $25 \cdot 0$ & $38 \cdot 5$ & $41 \cdot 0$ & $7 \cdot 420$ & $29 \cdot 5$ & $24 \cdot 8$ & 44.9 & $39 \cdot 5$ \\
\hline Average & $7 \cdot 428$ & $23 \cdot 3$ & 22.9 & 35.4 & 35.0 & 7.483 & $28 \cdot 6$ & $20 \cdot 8$ & $38 \cdot 7$ & $28 \cdot 9$ \\
\hline
\end{tabular}

TABLE III

$\mathrm{PCO}_{2}$ VALUES CALCULATED BEFORE AND DURING NITROUS OXIDE ANAESTHESIA USING THE MICRO-NATELSON AND/OR TECHNICON AUTOANALYZER TECHNIQUES SIMULTANEOUSLY WITH THE VOLUMETRIC VAN SLYKE AND MICRO-ASTRUP METHODS IN SEVERAL OF THE PATIENTS UNDERGOING ARTERIOGRAPHY

\begin{tabular}{|c|c|c|c|c|c|c|}
\hline \multirow{2}{*}{$\begin{array}{l}\text { Case } \\
\text { No. }\end{array}$} & \multicolumn{3}{|c|}{ Before $\mathrm{N}_{2} \mathrm{O}$ Anaesthesia } & \multicolumn{3}{|c|}{ During $\mathrm{N}_{2} \mathrm{O}$ Anaesthesia } \\
\hline & Van Slyke & Astrup & Micro-Natelson & Van Slyke & Astrup & Micro-Natelson \\
\hline $\begin{array}{l}\text { Case } \\
\text { No. }\end{array}$ & Van Slyke & Astrup & AutoAnalyzer & Van Slyke & Astrup & AutoAnalyzer \\
\hline $\begin{array}{l}3 \\
5 \\
\text { Average }\end{array}$ & $\begin{array}{l}29 \cdot 1 \\
34 \cdot 6 \\
31 \cdot 9\end{array}$ & $\begin{array}{l}28 \cdot 7 \\
32 \cdot 3 \\
30 \cdot 5\end{array}$ & $\begin{array}{l}30 \cdot 1 \\
34 \cdot 3 \\
32 \cdot 2\end{array}$ & $\begin{array}{l}35 \cdot 0 \\
51 \cdot 7 \\
43 \cdot 4\end{array}$ & $\begin{array}{l}26 \cdot 5 \\
40 \cdot 5 \\
33 \cdot 5\end{array}$ & $\begin{array}{l}27 \cdot 1 \\
36 \cdot 5 \\
31 \cdot 8\end{array}$ \\
\hline
\end{tabular}

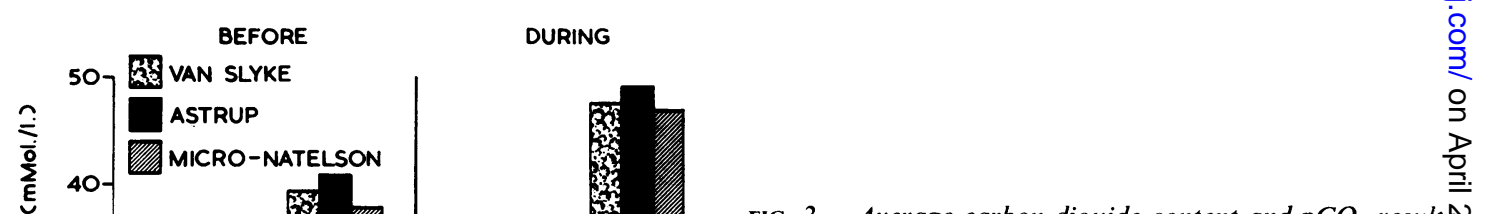

FIG. 3. Average carbon dioxide content and $\mathrm{pCO}_{2}$ result $\mathrm{N}$ measured or calculated simultaneously by the volumetris Van Slyke, micro-Astrup, and micro-Natelson technique 0 before and during halothane anaesthesia in 10 patient undergoing routine arteriography. Reasonable agreemenv of the results obtained by all three methods, both befors and during halothane anaesthesia, suggest that the volu metric Van Slyke carbon dioxide estimation is not affected? by this gaseous anaesthetic. 


\section{DISCUSSION}

The effect of volatile anaesthetic gases on the carbon dioxide content of serum measured by the Van Slyke technique was noted by Austin in 1924. When ether was added to dogs' blood in vitro such that the concentration was 1.0 to $1.8 \mathrm{mg}$. $/ \mathrm{ml}$., which is that associated with deep anaesthesia (White, 1923; Ronzoni, 1923), a considerable error was found to be produced in the volumetric and manometric Van Slyke carbon dioxide estimations. This error was due to the anaesthetic gas vapourizing in the vacuum chamber of the Van Slyke apparatus and thus adding to the volume of the extracted gases. To attempt to overcome this error, Austin developed a method which employed an empirical correction. This method subsequently gave way to the methods of Orcutt and Waters (1937) and Goldstein (1950), but the technical difficulties in estimating blood carbon dioxide accurately in the presence of different anaesthetic gases using a Van Slyke-Neill apparatus is emphasized in the paper by Holaday and Verosky (1955) when they compare these latter two methods.

Sodium or potassium hydroxide is often added to the Van Slyke apparatus as a 'specific' absorbent of carbon dioxide. Unfortunately, ether is highly soluble in both these absorbing agents whilst potassium hydroxide has a high affinity for nitrous oxide. However, Nunn (1958) has shown that nitrous oxide is not appreciably absorbed by sodium hydroxide. Thus in the presence of anaesthetic gases, strong alkali cannot always be safely assumed to be a specific absorbent of carbon dioxide. Furthermore, the added complication of adding sodium hydroxide is very often omitted quite validly in routine clinical estimations since the majority of estimations are carried out on blood from non-anaesthetized patients.

The difficulties and errors arising when the methods are used to study patients under anaesthesia are evident, with an error of about $25 \%$ in measured 'carbon dioxide content' and calculated $\mathrm{pCO}_{2}$ when the 'routine' volumetric Van Slyke procedure is used. In studies on cyanosis in nitrous oxide/oxygen anaesthesia in man (Raginsky and Bourne, 1934), the nitrous oxide content of the blood ranged from 16.8 to $21.7 \mathrm{vol}$. \% with an average of $18.8 \mathrm{vol}$. \% (about $8.4 \mathrm{mmol}$./1.). The presence of this amount of nitrous oxide in the average 'carbon dioxide content' of 28.6 $\mathrm{mmol} . / 1$. (as measured by the volumetric Van Slyke technique in the patients undergoing arteriography during the period of nitrous oxide anaesthesia) produces an error of about $29 \%$ in the measured 'carbon dioxide content', a difference of the same degree as our experimental findings. The $\mathrm{pCO}_{2}$ is, of course, a derived value and the large positive

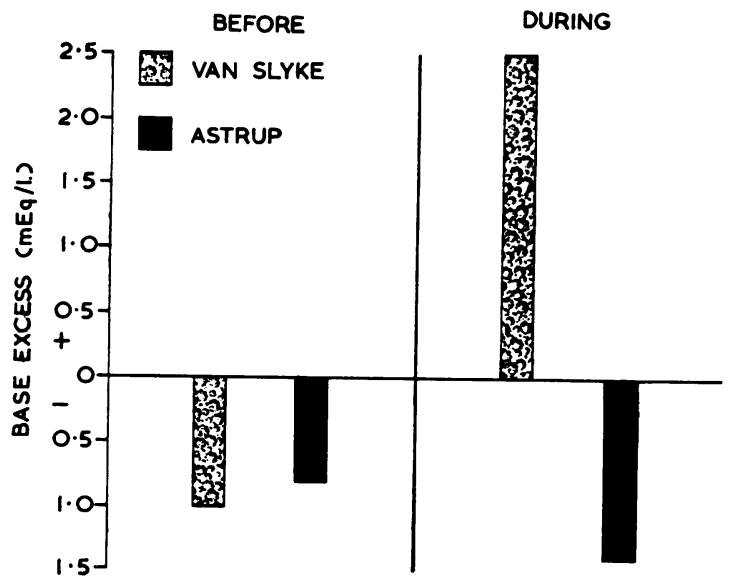

FIG. 4. Average 'base excess' before and during nitrous oxide anaesthesia for the 10 patients undergoing arteriography, calculated using the respective volumetric Van Slyke and micro-Astrup values in conjunction with the alignment nomogram of Siggaard-Andersen (1963). There is reasonable agreement in the results before anaesthesia, but a difference of almost $4 \mathrm{mEq} / \mathrm{l}$. in those during anaesthesia.

errors possible in the derivation of such values are obvious. When the 'base excess' is calculated using such data falsely positive results are again obtained (Fig. 4), the average variation in the normal patients being of the order of $4 \mathrm{mEq}$./ $\mathrm{l}$. Thus, for example, in states of mild metabolic acidosis the degree would be minimized and decisions on treatment often modified. No such errors were found when halothane was used as the gaseous anaesthetic, probably due to its much smaller effective concentration in blood.

We wish to thank the various anaesthetists for their kind cooperation; Miss P. Mathers, B.Sc., for the microNatelson analyses and the staff of the Clinical Chemistry section for the AutoAnalyzer measurements. We are also indebted to Dr. H. G. Morgan and Mr. W. F. Walker for their valuable advice and encouragement in preparing this script.

\section{REFERENCES}

Austin, J. H. (1924). J. biol. Chem., 61, 345.

Davenport, H. W. (1958). The ABC of Acid-Base Chemistry, 4th ed. University of Chicago Press, Chicago.

Goldstein, F., Gibbon, J. H. Jr., Allbritten, F. F. Jr., and Stayman, J. W. Jr. (1950). J. biol. Chem., 182, 815.

Holaday, D. A., and Verosky, M. (1955). J. Lab. clin. Med., 45, 149. - (1956). Ibid., 47, 634

Milch, R. A., Bane, H. N., and Roberts, K. E. (1957). J. appl. Physiol., 10,151 .

Morgan, H. G., Ogilvie, R. R., and Walker, W. F. (1963). J. clin. Path., $16,545$.

Natelson, S. (1961). Microtechniques of Clinical Chemistry, 2nd ed., p. 152. Thomas, Springfield, Illinois. , and Menning,C. M. (1955). Clin. Chem., 1, 165. 
Nunn, J. F. (1958). Brit. J. Anaesth., 30, 254.

Orcutt, F. S., and Waters, R. M. (1937). J. biol. Chem., 117, 509.

Peters, J. P., and Van Slyke, D. D. (1932). Quantitative Clinical Chemistry, vol. 2, (Methods), p. 229. Baillière, Tindall, and Cox, London.

Raginsky, B. B., and Bourne, W. (1934). Canad. med. Ass. J., 30, 518.

Ronzoni, E. (1923). J. biol. Chem., 57, 761.

Siggaard-Andersen, O. (1962). Scand. J. clin. Lab. Invest., 14, 598.
(1963). Ibid., $15 ., 211$.

Engel, K. Jorgensen, K., and Astrup, P. (1960). Ibid., 12, 17 万ु Singer, R. B., and Hastings., A. B. (1948). Medicine (Baltimore), 27, 223

Skeggs, L. T. (1960). Amer. J. clin. Path., 33, 181.

Walker, W. F Morgan, H. G., Breckenridge, I. N Ogilvie, R. R., and Douglas, D. M. (1963). Scot. med. J., 8, 14 C White, J. C. (1923). Arch. Surg., 7, 347.

\section{Broadsheets prepared by the Association of Clinical Pathologists}

The following broadsheets (new series) are published by the Association of Clinical Pathologists. They may be ob tained from Dr. R. B. H. Tierney, Pathological Laboratory, Boutport Street, Barnstaple, N. Devon. The prices includ $\bar{g}$ postage, but airmail will be charged extra.

3 The Detection of Barbiturates in Blood, Cerebrospinal Fluid, Urine, and Stomach Contents. 1953. L. C. NICKOLls. $1 \mathrm{~s}$.

13 The Identification of Serotypes of Escherichia coli Associated with Infantile Gastro-enteritis. 1956. JOAN TAYLOR. $1 \mathrm{~s}$.

16 Preservation of Pathological Museum Specimens. 1957 L. W. PROGER. 1s.

17 Cultural Diagnosis of Whooping-cough. 1957. B. W. LACEY. $1 \mathrm{~s}$.

20 Investigation of Porphyrin/Porphyria. 1958 (reprinted 1962). C. RIMINGTON. 2s.

23 The Dried Disc Technique for Bacterial Sensitivity Tests. 1959. R. W. FAIRBROTHER and J. C. SHERRIS. $1 \mathrm{~s}$.

24 Safe Handling of Radioactive Tissues in the Laboratory and Post-mortem Room. 1959. R. C. CURRAN. $1 \mathrm{~s}$.

26 The Periodic Acid-Schiff Reaction. 1959. A. G. E. PEARSE. 1s.

28 Daily Fatty Acid Excretion. 1960. A. C. FRAZER. 2s.

29 The Preparation of Bone for Diagnostic Histology. 1960. D. H. Collins. 2s.

30 Control of Accuracy in Chemical Pathology. 1961. G. H. GRANT. 4s.

31 Investigation of Haemorrhagic States with Special Reference to Defects of Coagulation of the Blood. 1961. E. K. BLACKBURN. 4s.

32 Detection of Resistance to Streptomycin, P.A.S., and Isoniazid in Tubercle Bacilli. 1961. R. CRUICKSHANK and $S$. M. STEWART. $2 \mathrm{~s}$.

33 The Laboratory Detection of Abnormal Haemoglobins. 1961. (reprinted 1965). H. LEHMANN and J. A. M. AGER. 4s.
34 Titration of Antistreptolysin O. 1961. H. GOODE and R. E. O. WILliams. $2 \mathrm{~s}$.

35 The Estimation of Faecal 'Urobilinogen'. 196 C. H. GRAY. $2 \mathrm{~s}$.

36 Quantitative Determination of Porphobilinogen ang Porphyrins in Urine and Faeces. 1961. C. RIMINGTON 3s. 6d.

37 The Paper Electrophoresis of Serum and Urinarm Proteins. 1961. G. FRANGLEN and N. H. MARTIN. 4\$

38 The Augmented Histamine Gastric Function Tes $\overrightarrow{6}$ 1961. M. LUBRAN. 2s.

39 Investigation of Haemolytic Anaemia. 1961. J. SELWYN. 2s.

40 Short-term Preservation of Bacterial Cultures 1962. E. JOAN STOKES. 2s.

41 Serological Tests for Syphilis. 1962. A. E. WILKI son. 6s.

42 The Determination of Glucose 6-Phosphate Dehy drogenase in Red Cells. 1962. T. A. J. PRANKERIS 2s.

43 Mycological Techniques. 1962. R. W. RIDDELE 3s. 6d.

44 The Laboratory Investigation of Catecholamine Secreting Tumours. 1963. M. SANDLER and C. R. RUTHVEN. 2s.

45 Diagnostic Test for Hereditary Galactosaemia. 196\$ v. SCHWARTZ. 2 s.

46 The Determination of Serum Iron and Total Irợ Binding Capacity. 1963. A. JORDAN and D. A: PODMORE. 2s.

47 Nuclear Sexing. 1964. B. LENNOX and w. DAVIDSON. $2 \mathrm{~s}$.

48 The Laboratory Investigation and Control of tide Defibrination Syndrome. 1964. R. M. HARDISTP G. I. C. INGRAM, and A. A. SHARP. 3s. 6d. 